\title{
ECONOMICS OF SNAIL PRODUCTION IN EDO STATE, NIGERIA
}

\author{
AHMADU J.1* AND OJOGHO 0.2 \\ 1Department of Agricultural Economics and Extension Services, Faculty of Agriculture, University of Benin, Benin City, Nigeria. \\ 2Department of Agricultural Economics, Faculty of Basic and Applied Sciences, Benson Idahosa University, Ugbor, Edo State, Nigeria. \\ *Corresponding Author: Email- joahma@yahoo.com
}

Received: May 21, 2012; Accepted: June 06, 2012

\begin{abstract}
The study examined the economics of snail production in Edo state of Nigeria. The socio-economic characteristics of the respondents cost and returns and factors affecting revenue generation in snail production were the specific areas of focus of the study. Snow balling sampling technique was adopted to identify a total of 95 snail farmers in the study area and this formed the sample size for the study. Data analysis was done using descriptive statistics, budgetary and regression analyses. The results indicated that the respondents had average stock size of 630 snails. The business of snail production required low capital investment and was highly profitable with gross margin and net profit per snail of N68.45 and N63.44 respectively. The results further showed that stock size, labor cost and educational level were the significant factors influencing revenue from snail production. They all correlated positively with the revenue and explained about $79 \%$ of the variation in the revenue $\left(R^{2}=0.785\right)$. It was concluded that since snail production required low capital investment, low income earners could comfortably embark on it; and in view of the high profit level of the business, it could be a veritable enterprise for uplifting the living standard of its producers and advance the economy of the nation.
\end{abstract}

Key words- Economics, Cost, profitability, Snail, Production, Nigeria.

Citation: Ahmadu J. and Ojogho O. (2012) Economics of Snail Production in Edo State, Nigeria. International Journal of Agriculture Sciences, ISSN: 0975-3710 \& E-ISSN: 0975-9107, Volume 4, Issue 5, pp-233-237.

Copyright: Copyright@2012 Ahmadu J. and Ojogho O. This is an open-access article distributed under the terms of the Creative Commons Attribution License, which permits unrestricted use, distribution, and reproduction in any medium, provided the original author and source are credited.

\section{Introduction}

There has been growing concerns in the recent years at the low level of protein intake, especially of animal origin in Nigeria as well as in other developing countries of the world. In spite of the various agricultural development strategies adopted in Nigeria to boost agricultural production, including livestock, daily per capita animal protein intake remains at less than $10 \mathrm{~g}$ which is a far cry from the Food and Agriculture Organization (FAO) recommended minimum requirement of $35 \mathrm{~g}$ [1]. In order to bridge this gap, there is need to explore other sources of animal protein in addition to the conventional sources such as ruminants and poultry. One of the important alternative sources of the animal protein which has received relatively scanty attention in Nigeria is the snail [2].

Snail is a crawling exo-skeletal invertebrate animal which belongs to the group of animals called Molluscs [3]. The importance of snail to man is enormous. Snail meat has been consumed by humans throughout the world since pre-historic times. It is high in protein $\left(45-50 \mathrm{mg}^{-1}\right)$, low in fat $(0.05-0.8 \%)$ and contains almost all the amino acids needed by humans [4]. In addition to the nutritional value of snail meat, it plays an important role in folk medicine. Snail is considered important in the treatment of anaemia. The bluish liquid obtained from the shell of the snail when the flesh has been removed is believed to be good for infant development. The low fat content in snail meat makes it a good antidote for fat-related diseases such as hypertension [5]. The Zinc obtained from snail is a valuable factor in the maintenance of healthy prostate gland [6]. The glandular substances from the edible snail cause agglutination of certain bacteria which could be of value against a variety of ailments including whooping cough [4].

Studies have also indicated that many products from snails farming are useful in other agricultural applications thereby enhancing 
its economic value. For instance, the feasibility of using snail meal of the giant African snail as a partial fishmeal substitute in raising fish such as Claris gariepinus [2]. Snails also fit in well with other farming activities helping to fertilize the soil prior to cultivation of other crops [7]. Furthermore, snail enterprise provides employment opportunities and income for the snail producers and marketers.

In view of the numerous nutritional and medicinal values of snail to humans, it has become a significant part of the daily diets of a large population of Nigeria, especially the tribes in the coastal and forest regions $[3,8]$. Consequently, there is a high demand for snails and this has been increasing with the supply lagging behind. It has become very important, therefore, to increase the production of snails to meet the ever increasing demand. To achieve this, economic analysis of snail production is necessary to provide convincing proof to investors of the profitability and otherwise of the business.

It is in view of this that this study examined the economics of snail production in Edo State of Nigeria. The study specifically examined the socio-economic characteristics of snail producers, estimated the cost and returns in snail production and examined the factors affecting revenue generation in snail production in the study area.

\section{Methodology \\ Study Area}

The study was conducted in Edo State of Nigeria. Edo State is located in the south western region of Nigeria which is the forest zone of the country. It lies between latitudes $4045^{\prime}$ and $7040^{\prime}$ North of the Equator and longitudes $5^{0}$ and $6^{0} 45^{\prime}$ East of prime meridian. It covers land area of $17,802 \mathrm{~km}^{2}$ with the population of $3,218,332$ people according to 2006 national population census [9]. The state has two distinct climatic seasons: the wet season which starts by April and ends by October and the dry season which is from November to March. Relative humidity and rainfall are high giving rise to thick vegetation cover. The major occupation of the inhabitants of the study area is agriculture. Agricultural practices carried out in the area include arable and tree crops production, fishing, snailry, aquaculture, poultry and livestock rearing.

\section{Sampling Technique}

Edo south agro-ecological zone was purposively selected from the 3 agro-ecological zones of the state (others are Edo North and Central agro-ecological zones) for the study. This choice was made because of the dominance of snail production in the zone. $A$ random sampling technique was applied to select 3 blocks (Egor, Ikpoba-Okha and Oredo) from the 7 blocks of the zone (others include Ovia North-East, Ovia South-West, Orhionmwon and Uhunmwode). Snow balling sampling technique which involves the establishment of personal contact with the respondents to build up the required sample was used to identify the snail farmers one after the other in these 3 blocks. This was done with the assistance of extension agents of Edo State Agricultural Development Project (ADP) and snails marketers at sales points. The population of the snail farmers identified in Egor, Ikpoba-Okha and Oredo were 26, 32 and 37 respectively. Because the snail farmers were not so many, all of them were used for the study, giving a total sample size of 95 respondents.

\section{Data Collection}

Data for the study were collected by means of a well-structured and pre-tested questionnaire complemented by personal interview. Data were collected on the socio-economic characteristics of the respondents, types of snails reared, and inputs and output quantities as well as their unit prices. The survey was carried out in 2011 .

\section{Validity and Reliability of Questionnaire}

The validity of the questionnaire was tested using content validity. The simplest and most direct method given by Wilkinson [10] was used and the content of the questionnaire was adjudged 'satisfied' by professional in the field of Agricultural Economics. Reliability of the instrument was tested using the test-retest technique. Copies of the questionnaire were first administered twice and pearson correlation coefficient between the two sets of responses was computed. High correlation coefficient was obtained indicating that the research instrument was reliable.

\section{Data Analysis}

Data analysis was done using descriptive statistics, budgetary and regression analyses.

\section{Descriptive Statistics}

These include the use of mean, frequency distribution, percentages and tables.

\section{Budgetary Analysis}

The budgetary analysis was used to determine the cost and returns to snail production in the study area. This involves determining the profitability of the snail production in the short-run when fixed costs are considered negligible using gross margin; and the net profit in the long-run by incorporating fixed costs into the analysis. The gross margin [11] is given as:

$\mathrm{GM}=\mathrm{GI}-\mathrm{TVC}$

Where: $\mathrm{GM}=$ Gross margin $(\mathrm{N}), \mathrm{GI}=$ Gross income $(\mathrm{N})$ and TVC $=$ Total Variable cost $(\mathrm{N})$

The net profit is given as: $\pi=\mathrm{GM}-\mathrm{TFC}$

Where: $\pi=$ Net profit, TFC $=$ Total fixed cost and GM is as previously defined.

\section{Regression Analysis}

This was used to examine the factors affecting the revenue from snail production. The relationship, according to Doll and Orazem [12] is implicitly expressed as

$Y=f\left(X_{1}, X_{2}, X_{3}, X_{4}, X_{5}, X_{6}\right.$, ei $)$

Where: $Y=$ Revenue from snail production $(\mathrm{N})$

$X_{1}=$ stock size, $X_{2}=$ cost of feeds, $X_{3}=$ labor cost, $X_{4}=$ fixed cost, $X_{5}=$ educational level, $X_{6}=$ farming experience (years), and $e_{i}=$ error term.

Three (3) functional forms of production model including linear, semi-log and Cobb-Douglas functions were fitted for the regression analysis. This was done to select the function which gave the result with the best fit. 


\section{Result and Discussion}

\section{Socio-Economic Characteristics of Snail Farmers}

The results of the socio-economic characteristics of the respondents presented in table 1 showed that majority $(74 \%)$ of the respondents were males, implying the dominance of males in the snail production industry. Aiyeloja and Ogunjinmi [13] also reported the dominance of males $(90 \%)$ in snail production. This is contrary to the expectation that a simple, less tedious and low capital intensive business like snail production would be dominated by women. There is need to encourage women to be involved in a business of this nature. The respondents were found to be relatively young (39 years) which means they might be vibrant in the snail production business. Majority $(73 \%)$ of them were married with high family sizes (7 persons/family on the average). The dominance of the married farmers among the respondents might be due to the desire to cater for their families. The implication of high family size is the large number of persons to cater for and this might have negative effect on the business. On the contrary, the family members might contribute significantly to labor operation thereby influencing the business positively.

Table 1- Socio-economic Characteristics of Respondents

\begin{tabular}{|c|c|c|}
\hline \multicolumn{2}{|r|}{ Gender } & Percentage (100) \\
\hline Male & 70 & 74 \\
\hline $\begin{array}{l}\text { Female } \\
\text { Age (years) }\end{array}$ & 25 & 26 \\
\hline $21-30$ & 15 & 16 \\
\hline $31-40$ & 41 & 43 \\
\hline $41-50$ & 11 & 12 \\
\hline $51-60$ & 3 & 8 \\
\hline $61-70$ & 20 & 21 \\
\hline Average & 39 & \\
\hline \multicolumn{3}{|c|}{ Marital status } \\
\hline Single & 22 & 23 \\
\hline Married & 73 & 77 \\
\hline \multicolumn{3}{|c|}{ Family size (persons) } \\
\hline $1-4$ & 27 & 37 \\
\hline $5-8$ & 38 & 52 \\
\hline $9-12$ & 8 & 11 \\
\hline Average & 7 & \\
\hline \multicolumn{3}{|c|}{ Educational level } \\
\hline No formal education & 2 & 2 \\
\hline Primary school & 3 & 3 \\
\hline Secondary school & 17 & 18 \\
\hline Tertiary education & 55 & 58 \\
\hline Adult education & 18 & 19 \\
\hline \multicolumn{3}{|c|}{ Farming experience (years) } \\
\hline $1-3$ & 57 & 60 \\
\hline $4-6$ & 25 & 26 \\
\hline $7-9$ & 13 & 14 \\
\hline Average & 3 & \\
\hline
\end{tabular}

Source: Field survey, 2011

The results further showed that snail production in Edo State was a business for the literate farmers. This is evidenced by $92 \%$ of the respondents that had at least primary or adult education with the majority $(58 \%)$ having tertiary education. This corroborates the findings of Ogunniyi [14] who reported that most (59\%) of snail farmers were educated; and Aiyeloja and Ogunjinmi [13] who estimated that all respondents involved in snail production had tertiary education. The high level of literacy of the respondents might afford them some level of managerial ability in their production enterprise. The respondents, however, had low years of experience in snail farming and this might affect their managerial ability.

\section{Stock Size and Specie of Snail Reared}

The stock size and species of snails reared are shown in Table 2. The respondents had average stock size of 630 snails, which is very close to the average stock size of 650 snails reported by Baba and Adeleke [15]. This is rather low and might be the key reason for the wide gap between supply and demand for snails [16]. The shortage in supply further affected the cost of snails in the market which was as high as about N100.00 per snail (Table 3 ). Most of the respondents reared Achatina archtina species of snail. This might not be unconnected with its wide distribution in Africa in addition to the fact that it is meatier and tenderer than other specials of [4].

Table 2- Stock Size and Specie of Snail Reared

\begin{tabular}{|lll|} 
Variable & $\begin{array}{l}\text { Frequency (95) } \\
\text { Stock Size }\end{array}$ & Percentage (100) \\
\hline $101-400$ & 23 & 24 \\
$401-700$ & 34 & 36 \\
$701-1000$ & 26 & 27 \\
$1001-1300$ & 12 & 13 \\
Average & 630 & \\
\multicolumn{4}{c}{ Specie of Snail } \\
Archachatina Marginata & 33 & 35 \\
Archatina archatina & 62 & 65 \\
\hline
\end{tabular}

Source: Field Survey, 2011

Table 3- Cost and returns in snail production in Edo State

\begin{tabular}{|c|c|c|c|}
\hline Variable & $\begin{array}{c}\text { Value/respondent } \\
\text { Returns }\end{array}$ & Value/snail & $\%$ of total cost \\
\hline Output (Number of snails) & 630 & 1 & - \\
\hline Selling price/snail $(\mathrm{N})$ & 100.2 & 100.2 & - \\
\hline Gross income (N) & $63,126.00$ & 100.2 & - \\
\hline \multicolumn{4}{|c|}{ Variable costs $(\mathrm{N})$} \\
\hline Feed & $6,835.50$ & 10.85 & 29.52 \\
\hline Labour & $12,996.90$ & 20.63 & 56.12 \\
\hline Medication & 170.1 & 0.27 & 0.73 \\
\hline Total variable cost & $20,002.40$ & 31.75 & 86.37 \\
\hline \multicolumn{4}{|c|}{ Fixed costs $(\mathrm{N})$} \\
\hline Depreciation of fixed inputs & $2,349.90$ & 3.73 & 10.15 \\
\hline Breeding stock & 756 & 1.2 & 3.26 \\
\hline Market tax & 50 & 0.08 & 0.22 \\
\hline Total fixed cost & $3,155.90$ & 5.01 & 13.63 \\
\hline Total cost & $23,158.30$ & 36.76 & 100 \\
\hline Gross margin (N) & $43,123.60$ & 68.45 & 186.21 \\
\hline Net profit $(\mathrm{N})$ & $39,967.70$ & 63.44 & 172.58 \\
\hline Return/N invested (N) & 1.73 & 1.73 & - \\
\hline
\end{tabular}

Source: Field survey, 2011

\section{Cost and Returns in Snail Production}

Table 3 shows the results of the cost involved and the returns in snail production in the study area. Snail production required as low as about N37.00 only to raise a snail to an average marketable size. The total variable cost relative to the total fixed cost was large (86.37\%) because of the low fixed capital inputs involved, indicating that snail production requires little capital investment. 
Labor cost was the largest component of the total cost (56.12\%). This is at variance with the other types of livestock such as poultry where feed is the most expensive input [17]. This may be due to the fact that most of the respondents fed snails with vegetative materials such as cassava leaves and pawpaw peels obtained from the farms and nearby bushes. The costs of these vegetative materials might be low but the labor involved in obtaining them might have contributed to the high labor cost. This finding confirmed the assertion that snail production requires little capital investment $[2,15]$. Besides, Cobbinah, Vink and Onwuka [2] reported that in snail production both technical, labor and other financial inputs requirements are relatively low compared with those in other categories of livestock farming such as poultry, pigs, goats, sheep, cattle and cane rate. Thus, snail production is a business which low income earners as well as the uneducated could comfortably embark upon. Enlightenment of farmers in this direction is very vital.

The results further indicated that snail production was highly profitable (net profit $=\mathrm{N} 63.44 /$ snail). Every naira invested in the business generated N1.73. In confirmation of the profitability of snail production, Baba and Adeleke [15] reported the net profit per snail and return per naira invested of $\mathrm{N} 40.00$ and N1.37 respectively. The returns on investment in snail production exceed those of other livestock categories such as poultry. For instance, the return per naira invested of N0.59 was reported for table egg production [18]. This indicates high economic potential in snail industry for uplifting the living standard of the rural poor and advancing the economy of the nation.

\section{Determinants of Revenue Generation in Snail Production}

The results of the regression analysis showing the relationship between the revenue from snail production and the factors influencing the revenue are presented in Table 4.

Table 4- Regression Analysis: Determinants of Revenue in Snail Production

\begin{tabular}{|llll} 
Variable & $\begin{array}{l}\text { Linear function } \\
\text { Coefficient }\end{array}$ & $\begin{array}{l}\text { Semi log function } \\
\text { Coefficient }\end{array}$ & $\begin{array}{l}\text { Cob-Douglas function } \\
\text { Coefficient }\end{array}$ \\
\hline Constant & -18293.67 & 731139.22 & 1.9 \\
& $(-0.788)$ & -0.878 & -3.81 \\
Stock size & 0.534 & 0.381 & 0.243 \\
& $(3.255)^{*}$ & $(1.680)^{* *}$ & $(2.044)^{* *}$ \\
Cost of feed & -0.283 & 0.396 & 0.16 \\
& $(-1.100)$ & $(1.730)^{* *}$ & -0.751 \\
Labour cost & 1.02 & -0.18 & 0.05 \\
& $(8.730)^{*}$ & $(-0.750)$ & -0.23 \\
Depreciated cost & 0.005 & -0.478 & -0.098 \\
& -0.003 & $(-2.162)^{*}$ & $(-0.392)$ \\
Educational level & 0.914 & 0.098 & 0.554 \\
& $(1.798)^{* *}$ & -0.738 & $(7.924)^{*}$ \\
Farming experience & -0.001 & 0.145 & 0.01 \\
$R^{2}$ & $(-0.008)$ & -1.105 & -0.91 \\
Adjusted R 2 & 0.785 & 0.189 & 0.368 \\
F-value & 0.764 & 0.097 & 0.296 \\
\hline
\end{tabular}

Source: Field survey, 2011, "significant at 1\%, ${ }^{* *}$ significant at $10 \%$, Figures in parentheses are $t$-values

The factors included stock size, cost of feed, labor cost, depreciated cost, educational level and farming experience. Based on the criteria for the selection of the lead equation given by Koutsoyannis [19], the linear function was chosen. The results of the linear function showed that about $79 \%$ of the variation in the revenue from snail production was explained by the changes in the factors under consideration. The F- statistic was significant at $1 \%$ level of significance indicating a good fit for the model used. Thee influences of stock size, labor cost and educational level on the revenue were significant. The positive signs of stock size and educational level confirmed to a priori expectation that increased in these inputs increased the level of revenue generated. Contrary to expectation, labor cost correlated positively with the revenue. The positive and significant effect of stock size corroborates the finding of Baba and Adeleke [15]. The effects of feed cost, depreciated cost and farming experience on the revenue were not significant confirming their low values as indicated in Tables 1 and 3.

\section{Conclusion/Recommendations}

The economics of snail production in Edo State of Nigeria had been examined in this study. It was established that snail production required low capital investment and hence it is a business in which low income earners could comfortably embark upon. It was also found that the business of snail production was high profitable and so could serve as a veritable enterprise for uplifting the living standard of its producers and consequently advanced the economy of the nation.

Base on the findings of this study, it is hereby recommended that low income earners should be encouraged to invest in snail production since it requires low capital investment. Low involvement of women in snail production also requires that they should be encouraged to go into the business. Sensitization of both the low income earners and women through extension services should be intensified. Furthermore, in view of the low level of snail production and the high profit generated from it, investors should embark on large-scale snail production. Policy thrust of the government should be geared specifically towards achieving large-scale snail production in the country.

\section{References}

[1] Usman J.S., Kehinde A.S., Ojo M.O., Akinyemi O. and Adebayo O. (2003) Proceedings of the 28th Annual Conference of the Nigerian Society for Animal Production, 411-412.

[2] Cobbinah J.R., Vink A. and Onwuka B. (2008) Snail Farming: Production, Processing and Marketing. Agrodok 47 and CTA.

[3] Yoloye V.L. (1984) Inaugural Lecture, University of Ilorin Ilorin, Nigeria.

[4] Cobbinah J.R. (1992) Snail Farming in West Africa: A Practical Guide. Technical Center for Agricultural and Rural Cooperation (CTA), 49.

[5] Imevbore E.A. (1990) Ph.D. Thesis, University of Ibadan, Nigeria.

[6] Fabian S.S. (1999) Utilization of Forestry Wildlife in West Africa. 15th Edition, Washington D.C.

[7] Leeflang M. (2005) Agromisa-AgroBrief, 3, 6.

[8] Ademolu K.O., Idowu A.B., Mafiana C.F. and Osinoiro O.A. (2004) Afr. J. Biotech. 3(8), 412-417.

[9] Nigeria/Africa Masterweb (2006) www.nigeriamasterweb.com/ Nigeria06CensusFigs.html.

[10]Wilkinson R.I. (2001) Bill System Technical J., 20, 265. 
[11]Utomakili J.B and Aganmwonyi F.E. (1995) Farm Management, Nigeria, 141-159.

[12]Doll J.P. and Orazem F. (1978) Production Economics, Theory with Applications. Grid Inc., Columbus Ohio, USA, 17-73.

[13]Aiyeloja A.A. and Ogunjinmi A.A. (2010) World Academy of Sci., Engineering and Tech. 72, 614-618.

[14]Ogunniyi L.T. (2009) Int. J. Agric. Econs. and Rural Dev. 2(1), 26-34.

[15]Baba K.M. and Adeleke M.T. (2006) J. Agric. and Food Sci. 4, 147-155.

[16]Etchu K., Mafeni M. and Ngenwi A. (2008) Bull. Anim. Health Prod. Afr., 56, 345-352.

[17]Ahmadu J., Erhabor P.O. and Jimoh M. (2010) 11th Annual National Conference of National Association of Agricultural Economists (NAAE) on Commercial Agriculture, Banking Reform and Economic Downturn, Setting a New Agenda for Agricultural Development in Nigeria, 27-33.

[18]Njoku M.S. and Adaeze E. (2003) 28th Annual Conference of the Nigerian Society for Animal Production, 413-415.

[19]Koutsoyannis A. (1977) Theory of Econometrics, 2nd Edition, 55-57, 197-253. 